\title{
HUBUNGAN ANTARA KOMPETENSI PROFESIONAL GURU DENGAN HASIL BELAJAR IPA SISWA KELAS V SD GUGUS II KECAMATAN TANETE RIATTANG KABUPATEN BONE
}

\author{
Iswandi ${ }^{1}$, Muhammad Amran ${ }^{2}$, Satriani $\mathrm{DH}^{3}$, Rasmi Djabba ${ }^{4}$ \\ ${ }^{1}$ Universitas Negeri Makasar, \\ Email:iswansandi7@gmail.com \\ 2 Universitas Negeri Makasar, \\ Email:neysaamran@yahoo.co.id \\ ${ }^{3}$ Universitas Negeri Makasar \\ Email:Satriani.dh@gmail.com \\ ${ }^{4}$ Universitas Negeri Makasar \\ Email:rasmidjabba@unm.ac.id
}

\begin{abstract}
Abstrak
Masalah dalam penelitian ini adalah kurangnya pemahamangurumengenai kompetensi profesional guru,yakni penguasaan materi secara luas dan mendalam,serta penggunanan media dan fasilitas belajar secara efektif.Penelitian ini merupakan penelitian kuantitatif dengan desain korelasi yang bertujuan untuk mengetahui gambaran kompetensi profesional guru dengan hasil belajar IPA siswa kelas V Gugus II.Hasil penelitian ini menunjukkan bahwa terdapat hubungan yang signifikan antara kompetensi profesional guru dengan hasil belajar IPA di SD gugus II dengan nilai $t_{\text {hitung }}(4,050)$ lebih besar $(>)$ nilai $t_{\text {tabel }}(1,68830)$ pada taraf signifikansi 5\%. Dengan demikian $\mathrm{H}_{0}$ ditolak $\mathrm{H}_{1}$ diterima. Berdasarkandari hasil analisis data di atas dapat disimpulkan bahwa kompetensi profesional akan berdampak pada hasil belajar IPA siswa. Jadi semakin baik kompetensi profesional guru maka akan meningkatkan hasil belajar siswa. Dari kesimpulan tersebut, maka dampak yang dihasilkan dari penelitian ini diketahui bahwa kompetensi profesional yang baik akan meningkatkan hasil belajar siswa.
\end{abstract}

Kata Kunci: Profesional Guru, Hasil Belajar, IPA

\begin{abstract}
The problem in this study is the teacher's lack of understanding of the professional competence of teachers, namely broad and deep mastery of the material, as well as the effective use of media and learning facilities. This research is a quantitative research with a correlation design that aims to describe the professional competence of teachers with learning outcomes in science for class V Cluster II students. The results of this study indicate that there is a significant relationship between teacher professional competence and science learning outcomes in elementary school cluster II with a greater t_count (4.050) value (>) $t$ _value (table )(1.68830) at a significance level of 5\%. Thus $\mathrm{HO}$ is rejected $\mathrm{H} 1$ is accepted. Based on the results of the data analysis above, it can be concluded that professional competence will have an impact on students' science learning outcomes. So the better the professional competence of the teacher, the better the student learning outcomes. From these conclusions, the impact resulting from this study is known that good professional competence will improve student learning outcomes.
\end{abstract}

Keywords: Teacher professionals, Learning outcomes, Science 
Pendahuluan

Pendidikan merupakan suatu usaha atau kegiatan yang dijalankan dengan sengaja, teratur dan terencana dengan maksud mengubah atau mengembangkan perilaku yang diinginkan peserta didik. Pendidikan juga merupakan faktor yang sangat penting dalam kehidupan berbangsa dan bernegara karena akan sangat menentukan maju tidaknya suatu bangsa. Hal ini sejalan dengan UU No. 20 tahun 2003 tentang Sistem Pendidikan Nasional pada pasal 1 ayat (1).Hakim (2016) bahwa pendidikan merupakan usaha sadar serta terencana untuk mewujudkan suasana belajar agar siswa secara aktif dapat mengembangkan potensinya untuk memiliki kekuatan yang spiritual keagamaan, pengendalian dirinya, masyarakat, bangsa dan negara.

Pendidikan menuntut orang yang terlibat di dalamnya untuk bekerja sama secara maksimal, penuh rasa tanggung jawab, dan loyalitas yang tinggi dalam meningkatkan mutu pendidikan. Guru merupakan salah satu komponen paling menentukan dalam sistem pendidikan secara keseluruhan, yang harus mendapat perhatian utama dalam peningkatan kualitas pendidikan. Guru memegang peran utama dalam bangunan pendidikan,khususnya yang diselenggarakan secara formal di sekolah.Hal tersebut sangat menentukan keberhasilan peserta didik, terutama dalam kaitannya dengan proses belajar mengajar. Guru merupakan tenaga profesional yang bertugas melaksanakan proses pembelajaran, menilai hasil pembelajaran, melakukan pembimbingan dan pelatihan serta melakukan penelitian. Guru perlu dibekali untuk melakukan tugasnya dengan pengetahuan yang baik dan juga relevan dengan perkembangan zaman

(Syah, 2010) menyatakan bahwa untuk melakukan tugasnya, tenaga pendidik sangat memerlukan berbagai pengetahuan dan keterampilan keguruan yang memadai sesuai dengan tuntutan zaman dan kemajuan sains dan teknologi. (Pratama, Bukhari, \& Mahmud, 2017). Berdasarkan hal tersebut, maka setiap guru dituntut untuk memiliki kompetensi. Kompetensi merupakan kecakapan seseorang dalam bidang yang digelutinya. Adapun kompetensi berdasarkan PP Nomor 74 Tahun 2008 tentang guru yaitu "Seperangkat pengetahuan, keterampilan, dan perilaku yang harus dimiliki, dikuasai, dan diaktualisasikan oleh guru dalam melaksanakan tugas keprofesionalan" (Suarya et al., 2018). 
Kompetensi merupakan hal yang perlu dimiliki oleh setiap bidang pekerjaan termasuk profesi Guru. Menurut Suyanto \& Jihad (2013: 21) "Profesionalisme adalah sebutan yang mengacu kepada sikap mental dalam bentuk komitmen anggota suatu profesi untuk senantiasa mewujudkan dan meningatkan kualitas profesionalnya". Lebih spesifik Buchari (2009) menyatakan bahwa "Kompetensi profesional adalah kemampuan yang berhubungan dengan penyelesaian tugas-tugas keguruan" (Kurniati, 2014: 67).Berdasarkan pendapat tersebut dapat disimpulkan bahwa kompetensi profesional merupakan komitmen anggota suatu profesi khususnya guru untuk meningkatkan kemampuan dalam menyelesaikan tugas. Kompetensi profesional mengacu pada guru yang telah mendapat pengakuan yang berlaku, baik dalam kaitan dengan jabatan mupun latar belakang pendidikan formalnya. Pengakuan ini dinyatakan dalam bentuk surat keputusan, ijazah, akta, sertifikat,dan sebagainya baik yang menyangkut kualifikasi maupun kompetensi. Sebutan kompetensi profesional guru juga dapat mengacu kepada pengakuan terhadap penampilan unjuk kerja seseorang guru dalam melaksanaan tugas-tugasnya sebagai tenaga pengajar.

Kompetensi merupakan suatu keahlian yang dimiliki oleh setiap individu dalam setiap profesi yang digelutinya. Adapun pengertian kompetensi menurut $\mathrm{KBBI}$ "kompetensi merupakan kewenangan, kekuasaan, untuk memutuskan sesuatu atau kemampuan menguasasi gramatika suatu bahasa secara abstrak atau batiniah". (Indrawan, 2020: 25). Lebih lanjut menurut Broke dan Stone "Kompetensi sebagai descriptive of qualitative nature of teacher behavior appears to be entirely meaningful" (Mulyasa, 2013: 42). Artinya, kompetensi merupakan gambaran hakikat kualitatif dari perilaku guru atau tenaga kependidikan yang tampak sangat berarti.Hal ini berarti kompetensi merupakan perpaduan dari pengetahuan, keterampilan, nilai, dan sikap yang direfleksikan dalam kebiasaan berpikir dan bertindak.

UU Republik Indonesia nomor 14 tahun 2005 tentang Guru dan Dosen "Kompetensi adalah seperangkat pengetahuan, keterampilan, dan perilaku yang harus dimiliki, dihayati dan dikuasai oleh Guru atau Dosen dalam melaksanakan tugas keprofesionalan." Sejalan dengan itu, (Mulyasa, 2013: 26) menyatakan bahwa "Kompetensi Guru 
merupakan perpaduan personal, hal ini sesuai dengan pendapat yang keilmuan, teknologi, sosial, dan spiritual dikemukakan oleh Priansa (2014) yang membentuk kompetensi standar bahwa kompetensi profesional adalah profesi Guru, yang mencakup kemampuan penguasaan materi secara penguasaan materi, pemahaman mendalam yang harus dimiliki oleh guru terhadap peserta didik, pembelajaran agar pembelajaran menjadi lebih luas yang mendidik, pengembangan pribadi dan profesionalisme".

Secara umum, kompetensi guru mencakup kompetensi pribadi, kompetensi profesional, kompetensi pedagogik, dan kompetensi sosial. Hal tersebut sesuai dengan pendapat yang dikemukakan oleh (Musfah, 2011: 30) bahwa:Kompetensi pendidik yang dimaksud diantaranya: 1) Kompetensi pedagogik, yaitu kemampuan guru dalam mengelola pembelajaran peserta didik; 2) Kompetensi kepribadian, yaitu kemampuan yang berkaitan dalam perfomans pribadi seseorang peserta didik; 3) Kompetensi profesional, yaitu kemampuan penguasaan materi pembelajaran secara luas dan mendalam; 4) Kompetensi sosial, yaitu kemampuan berkomunikasi bergaul secara efektif dengan peserta didik, sesama pendidik, tenaga kependidikan, orang tua/wali peserta didik, dan masyarakat sekitar. Kompetensi Profesional guru merupakan penguasaan materi yang secara luas dan mendalam dengan harapan siswa mampu memenuhi standar kompetensi, yang memungkinkan terintegrasikannya pembelajaran dengan penggunaan TIK dengan harapan mampu membimbing siswa memenuhi standar kompetensi di dalam Standar Nasional Pendidikan. Sejalan dengan itu menurut Suparno kompetensi profesional berarti "Guru harus memiliki pengetahuan yang luas serta dalam tentang subject matteri (bidang studi) yang akan diajarkan, serta penguasaan metodologi dalam arti memiliki pengetahuan konsep teoritik, mampu memilih metode yang tepat, serta mampu menggunakan dalam proses belajar mengajar" (Arsyad, 2019: 67).

Adapun kriteria kompetensi menurut (Priansa, 2014) yang melekat pada kompetensi profesional guru meliputi:

1. Penguasaan konsep materi yang akan mendukung mata pelajaran yang diampuh.

2. Penguasaan standar kompetensi dan kompetensi dasar mata pelajaran/ bidang pengembangan yang diampu.

3. Mengembangkan materi pelajaran secara kreatif, inovatif dan mudah dipahami. 
4. Mengembangkan kompetensi keprofesionalan guru.

5. Pemanfaatan teknologi informasi dan komunikasi untuk berkomunikasi dan mengembangkan diri.

Sejalan dengan pendapat (Suyanto dan Jihad, 2013: 9) mengatakan bahwa setiap subkompetensi tersebut memiliki indikator esensial sebagai berikut:

a. Menguasai substansi keilmuan yang terkait dengan bidang studi. Hal ini berarti guru harus memahami materi ajar yang ada dalam kurikulum sekolah, memahami struktur, konsep, dan metode keilmuan yang menaungi dan koheren dengan materi ajar, memahami hubungan konsep antarmata-pelajaran terkait, dan menerapkan konsep-konsep keilmuan dalam proses belajar mengajar.

b. Menguasai struktur dan metode keilmuan memiliki implikasi bahwa guru harus menguasai langkah langkah penelitian dan kajian kritis untuk memperdalam pengetahuan/materi bidang studi.Belajar merupakan sesuatu yang berproses dan merupakan unsur yang fundamental dalam masing-masing tingkatan pendidikan. Menurut Hariyanto \& Suyono (2011) "belajar adalah suatu aktivitas atau suatu proses untuk memperoleh pengetahuan, meningkatkan keterampilan, memperbaiki perilaku, sikap, dan mengokohkan kepribadian". Sejalan dengan itu (Rusman 2016: 12) "belajar merupakan suatu aktivitas yang dapat dilakukan secara psikologis maupun secara fisiologis". Aktivitas yang bersifat psikologis yaitu aktivitas yang merupakan proses mental, misalnya aktivitas berpikir, memahami, menyimpulkan, menyimak, menelaah, membandingkan, membedakan, mengungkapkan, dan menganalisis. Sedangkan aktivitas yang bersifat fisiologis yaitu aktivitas yang merupakan proses penerapan atau praktik, misalnya melakukan eksperimen atau percobaan, latihan, kegiatan praktik, membuat karya (produk), dan apresiasi.

Siswa dikatakan berhasil dalam belajar apabila siswa mencapai tujuan pelajaran.Dalam dunia pendidikan hasil belajar berkaitan dengan perubahanperubahan pada diri siswa, baik yang menyangkut aspek kognitif, afektif dan psikomotorik. (Susanto, 2015: 5), "hasil belajar yaitu perubahan-perubahan yang 
terjadi pada diri siswa, baik yang menyangkut aspek kognitif, afektif, dan psikomotor sebagai hasil dari kegiatan belajar". Adapun (Purwanto, 2016: 45), "hasil belajar adalah perubahan yang mengakibatkan manusia berubah dalam sikap dan tingkah lakunya".

Pembelajaran IPA adalah salah satu pembelajaran yang menyenangkan karena memiliki sifat yang kontekstual. $\mathrm{Hal}$ ini sesuai dengan pendapat yang di kemukakan oleh (Isnaningsih dan Bimo, 2013) bahwa pembelajaran pada IImu Pengetahuan Alam (IPA) adalah kegiatan dalam suasana yang mengasyikan dan menyenangkan karena siswa mempelajari hal-hal yang bersifat kontekstual (Muslimin \& Amran, 2020).

Hasil belajar IPA dikelompokkan berdasarkan hakikat IPA itu sendiri yaitu sebagai produk dan proses. Hal ini berdasarkan pendapat Hungerford (Sidabutar, 2017: 60) yang menyatakan bahwa IPA terbagi atas dua yaitu (1) the investigation (proses) seperti mengamati, mengukur, meramalkan dan menyimpulkan, (2) the knowledge (produk) seperti fakta, konsep, prinsip, hukum dan teori IPA.

Berdasarkan hasil wawancara yang dilakukan oleh peneliti dengan guru kelas V di SD Gugus II Kecamatan Tanete Riattang Kabupaten Bone pada tanggal 2 sampai 6 februari 2021, guru masih

mengalami

berbagai

permasalahan yang berkaitan dengan kompetensi profesional guru. Masalah tersebut berkaitan dengan penguasaan materi pembelajaran secara luas dan mendalam yang harus dikuasai guru mencakup

penguasaan

materi,kemampuan menerapkan metode pembelajaran yang tepat, dan penggunaan berbagai media secara efeketif. Masih terdapat beberapa Guru yang tidak menguasai aspek aspek yang ada di dalam kompetensi profesional, misalnya tujuan pendidikan yang harus dicapai baik tujuan pendidikan nasional, tujuan institusional, tujuan kurikuler maupun tujuan pembelajaran. Kemudian pemahaman dalam bidang psikologi bidang pendidikan, misalnya paham tentang perkembangan peserta didik, paham tentang teori-teori belajar, kemampuan dalam penguasaan materi dalam materi sesuai bidang studi yang diajarkannya.Sedangkan kemampuan tersebut sebenarnya harus dimiliki dan dikuasai oleh guru karena sangat menunjang dalam kesuksesan suatu pembelajaran.

Berdasarkan penelitian sebelumnya yang pernah dilakukan oleh (Agusta Kurniati, 2019) dapat disimpulkan bahwa terdapat hubungan positif dan signifikan antara kompetensi profesional gurudengan hasil belajar IPA. 
Tujuan dari penelitian ini adalah untuk mengetahui gambaran kompetensi profesional guru dan gambaran hasil belajar IPA siswa kelas V SD Gugus II serta untuk mengetahui ada tidaknya hubungan yang signifikan antara kompetensi profesional dengan hasil belajar IPA siswa kelas V SD Gugus II. Berdasarkan tujuan tersebut dirumuskan hipotesis dari penelitian yang dilakukan yaitu terdapat hubungan yang signifikan antara kompetensi profesional guru denganhasil belajar IPA siswa kelas $\mathrm{V}$ SD Gugus II.

\section{METODE PENELITIAN}

Pendekatan yang akan digunakan dalam penelitian ini yaitu pendekatan kuantitatif dengan jenis penelitian korelasional. (Emzir, 2015: 28) mengemukakan bahwa:

Pendekatan kuantitatif adalah suatu pendekatan penelitian yang secara primer menggunakan paradigma postpositivist dalam mengembangkan ilmu pengetahuan (seperti pemikiran tentang sebab akibat, reduksi kepada variabel, hipotesis, dan pertanyaan spesifik, menggunakan pengukuran dan observasi, serta pengujian teori), menggunakan strategi penelitian seperti eksperimen dan survei yang memerlukan data statistik. Penelitian ini bertujuan untuk mencari hubungan antara kompetensi profesional guru dengan hasil belajar siswa kelas V SD Gugus II Kecamatan Tanete Riattang Kabupaten Bone.

Penelitian dilaksanakan pada semester ganjil tahun pelajaran 2020/2021.Penelitian dimulai 11Juni 2021 dan berakhir pada 23 Juni 2021.Bertempat di Sekolah Dasar Gugus II Kecamatan Tanete Riattang Kabupaten Bone, tahun ajaran 2020/2021.

Tahap pelaksanaan penelitian yang dilakukan yaitu calon peneliti melakukan pertemuan awal dengan pihak sekolah yang akan menjadi tempat penelitian (meminta izin secara lisan).Selanjutnya peneliti mengurus surat izin penelitian untuk kemudian diberikan kepada pihak sekolah tempat penelitian. Selanjutnya peneliti melakukan pertemuan dengan pihak wali kelas $\mathrm{V}$ untuk mengatur jadwal yang tetap untuk melakukan penelitian. Kemudian mengumpulkan data dengan membagikan angket kepada siswa. Selanjutnya yaitu menganalisis data.Dan yang terakhir peneliti menarik kesimpulan penelitian.

Teknik pengumpulan data yang dilakukan dalam penelitian ini ada tigacara yaitu angket, wawancara dan dokumentasi. Angket dalam penelitian ini 
untuk mengumpulkan dan memperoleh data dan informasi mengenai kompetensi profesional guru.Dalam penelitian ini menggunakan angket dalam bentuk skala likert. Menurut (Sugiyono, 2018: 134) "Skala Likert digunakan untuk mengukur sikap, pendapat, dan persepsi seseorang atau sekelompok orang tentang fenomena sosial. Dalam penelitian, fenomena sosial ini telah ditetapkan secara spesifik oleh peneliti, yang selanjutnya disebut sebagai variabel penelitian. Dengan skala likert, variabel yang akan diukur, dijabarkan menjadi indikator variabel. Kemudian indikator tersebut dijadikan sebagai titik tolak untuk menyusun item-item instrumen yang dapat berupa pernyataan atau pertanyaan.

Teknik dokumentasi yaitu cara mengumpulkan dan memperoleh data mengenai nama-nama dan nilai hasil belajar IPA siswa kelas V SD Gugus II Kecamatan Tanete Riattang Kabupaten Bone.

Teknik Analisis data adalah tekhnik yang digunakan untuk membuktikan hipotesis.Didalam penelitian ini, ada dua variabel yaitu variabel kompetensi profesional guru dan variabel hasil belajar siswa.Tekhnik analisis yang digunakan dalam penelitian ini yaitu tekhnik analisis statistik deskriptif dan analisis statistik inferensial.
Analisis statistik deskriptif digunakan untuk melihat gambaran kompetensi profesional gurudenganhasil belajar siswa yang digunakan dengan teknik analisis rata-rata dan analisis persentase. Sedangkan analisis statistik inferensial digunakan untuk menguji hipotesis penelitian yang digunakan dengan teknik ujiregresi linear, person product moment, determinasi dan uji-t.

\section{HASIL PENELITIAN}

Data yang diperoleh dan dianalisis merupakan skor dari angket kompetensi profesional guru dan nilai IPA untuk hasil belajar siswa kelas V SD Gugus II Kecamatan Tanete Riattang Kabupaten Bone.

\section{Kompetensi Profesional Guru kelas} V SD Gugus II Kecamatan Tanete Riattang Kabupaten Bone

Berdasarkan hasil pengolahan data, maka diketahui: $N=38, \sum f x=3107$, jadi analisis rata-rata adalah sebagai berikut:

$$
\bar{X}=\frac{3107}{38}=81,76
$$

Hasil perhitungan tersebut, menunjukkan bahwa analisis rata-rata skor variabel $X$ yaitu 81,76 
Adapun analisis standar deviasi yaitu:

$$
\begin{aligned}
& S D=\sqrt{\frac{\sum f X^{2}}{N}-\left(\frac{\sum f X}{N}\right)^{2}} \\
& S D=\sqrt{\frac{559723}{38}-\left(\frac{6539}{38}\right)^{2}} \\
& S D=\sqrt{\frac{559723}{38}-(84,92)^{2}} \\
& S D=\sqrt{7269,12-7211,40} \\
& S D=\sqrt{57,72} \\
& S D=6,29
\end{aligned}
$$

Hasil tersebut menunjukkan bahwa standar deviasi variabel kompetensi profesional gurusebesar 6,29 . Nilai standar deviasi yang diperoleh menunjukkan keragaman data atau variasi data. Hasil dari analisis rata-rata yakni 84,92>6,29 standar deviasi. Semakin tinggi standar deviasi yang diperoleh maka semakin banyak keragaman datanya yang berarti terdapat perbedaan nilai yang terlalu jauh.

Analisis persentase dilakukan setelah memperoleh analisis rata-rata dan diketahui jumlah skor yang diperoleh keseluruhan, $\mathrm{n}=\sum \mathrm{FX}$ yaitu 3107. Nilai yang diharapkan (N) yaitu jumlah responden dikali skor maksimal yakni 38 $x 100=3800$. Sehingga:

$$
\begin{aligned}
\mathrm{P} & =\frac{n}{N} \times 100 \% \\
& =\frac{3107}{3800} \times 100 \% \\
& =81,76 \%
\end{aligned}
$$

Hasil tersebut menunjukkan persentase skor variabel kompetensi profesional guru adalah 81,76\%. Maka diketahui bahwa kecerdasan interpersonal siswa kelas V SD Gugus II Kecamatan Tanete Riattang yakni berada pada kategori kuat.

Berdasarkan data kompetensi profesional yang diperoleh, agar lebih memudahkan dalam membaca data maka terlebih dahulu ditentukan kelas dari masing-masing kategori. Diketahui mean/nilai rata-rata 81,76 dan standar deviasi 6,29. Selanjutnya kelas dari masing-masing kategori dirincikan berikut:

1) Kelompok tinggi

$$
\begin{aligned}
& X \geq M+1 S D \\
& X \geq 81,76+1(6,29) \\
& X \geq 88,05
\end{aligned}
$$

2) Kelompok sedang

$$
\begin{aligned}
& (M-1 S D) \leq X<(M+S D) \\
& 81,76-1(6,29) \leq X<81,76+6,29 \\
& 75,47 \leq X<88,05
\end{aligned}
$$

3) Kelompok kurang

$$
\begin{aligned}
& (\mathrm{X}<\mathrm{M}-1 \mathrm{SD}) \\
& \mathrm{X}<81,76-1(6,29) / \\
& \mathrm{X}<75,47
\end{aligned}
$$

Sehingga diperoleh tabel dan diagram lingkaran sebagai berikut: 
Tabel 1. Pengkategorian Variabel Kompetensi Profesional Guru Kelas V SD Gugus II

\begin{tabular}{cccc}
\hline \multirow{2}{*}{ Nilai interval } & \multicolumn{2}{c}{ Frekuensi } & \multirow{2}{*}{ Kategori } \\
\cline { 2 - 3 } & Frekuensi & $\%$ & \\
\hline $\mathrm{X} \geq 88,05$ & 6 & 15,78 & Tinggi \\
$75,46 \leq \mathrm{X}<88,05$ & 25 & 65,78 & Sedang \\
$\mathrm{X}<75,47$ & 7 & 18,42 & Kurang \\
\hline Total & 38 & 100 & \\
\hline
\end{tabular}

Sumber: Hasil Angket Penelitian, 2021

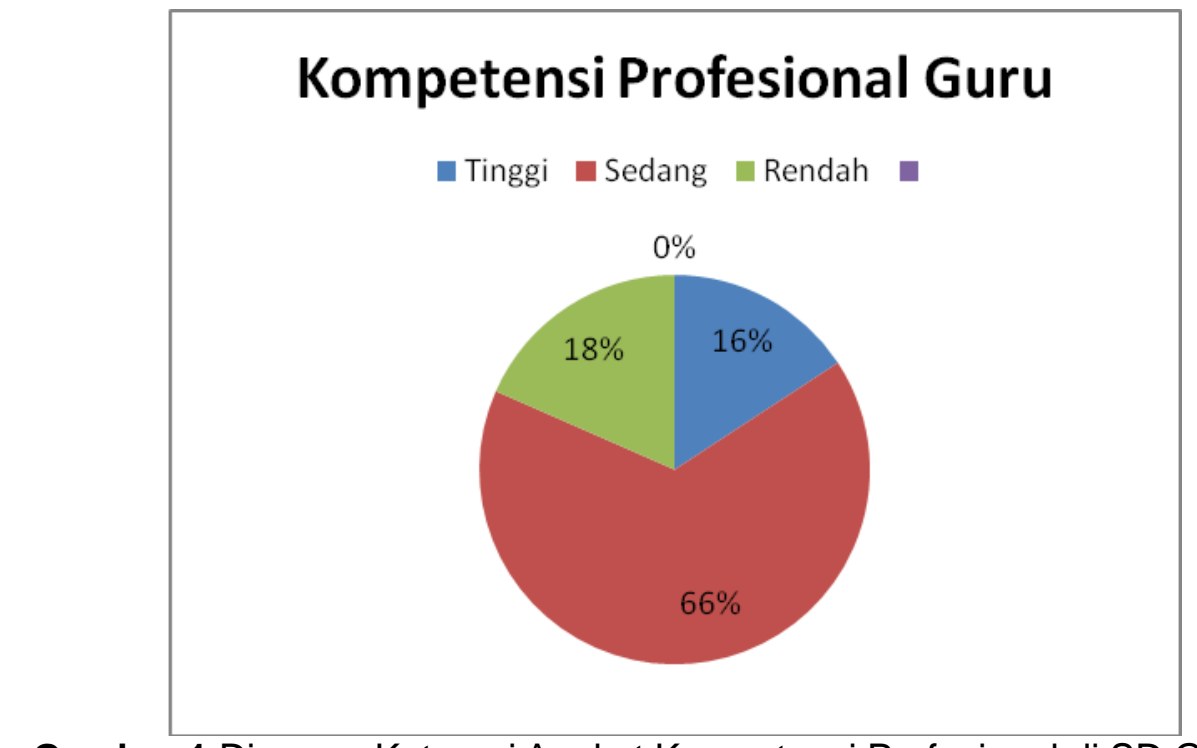

Gambar 1.Diagram Kategori Angket Kompetensi Profesional di SD Gugus II

Pengkategorian nilai angket siswa dengan persentase sebesar kompetensi profesional digambarkan 15,78 \% jawaban tersebut berada pada tabel dan gambar 1. pada nilai pada kategori tinggi, dan kategori terendah terdapat 7 siswa dengan dengan jumlah siswa terbanyak persentase sebesar 18,42\%, jawaban terdapat pada kategori sedang tersebut termasuk dalam kategori dengan jumlah siswa 25 dengan kurang, pada nilai tertinggi terdapat 6 persentase $65,78 \%$. 
Tabel 2. Distribusi Frekuensi Angket Kompetensi Profesional Guru SD Gugus II

\begin{tabular}{lccc}
\hline Interval kelas & $\mathbf{f}$ & $\mathbf{x}$ & $\mathbf{f x}$ \\
\hline $76-78$ & 3 & 77 & 231 \\
\hline $79-81$ & 1 & 80 & 80 \\
\hline $82-84$ & 5 & 83 & 415 \\
\hline $85-87$ & 16 & 86 & 1376 \\
\hline $88-90$ & 8 & 89 & 712 \\
\hline $91-93$ & 5 & 92 & 460 \\
\hline$\Sigma$ & 38 & & 3274 \\
\hline
\end{tabular}

Sumber: Hasil Angket Penelitian, 2021

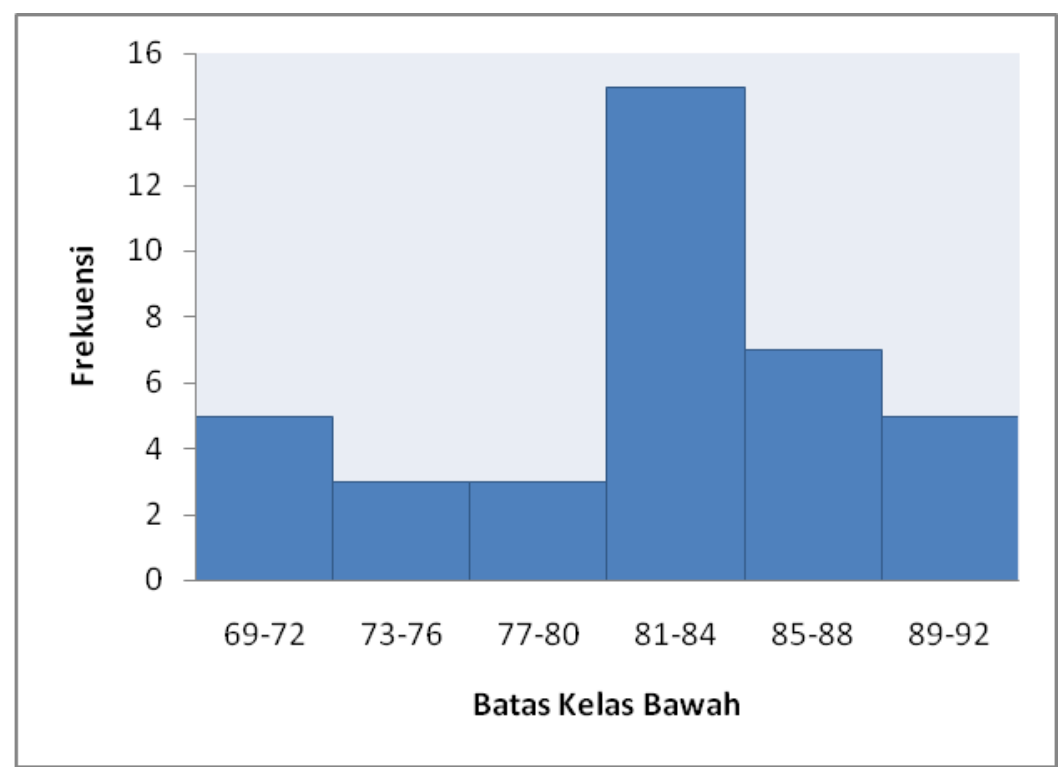

Gambar 2. Grafik Histogram Hasil Distribusi Frekuensi Skor Angket Kompetensi Profesional Guru Kelas V SD Gugus II

Dengan demikian, dapat disimpulkan pada kelas interval 85-89 dengan bahwa frekuensi paling tinggi terdapat jumlah siswa sebanyak 19 .

\section{Hasil Belajar Siswa Kelas V SD Gugus II}

3274 , jadi rata-rata adalah sebagai berikut:

Berdasarkan hasil pengolahan

$$
\bar{X}=\frac{3274}{38}=86,15
$$

data, maka diketahui: $\mathrm{N}=38, \Sigma \mathrm{fx}=$

$$
\begin{aligned}
& \text { Hasil perhitungan tersebut, } \\
& \text { menunjukkan bahwa rata-rata skor } \\
& \text { variabel } Y \text { adalah } 86,15 \text {. }
\end{aligned}
$$


Adapun analisis standar deviasi yaitu:

$$
\begin{gathered}
S D=\sqrt{\frac{\sum f X^{2}}{N}-\left(\frac{\sum f X}{N}\right)^{2}} \\
S D=\sqrt{\frac{502067}{38}-\left(\frac{6203}{38}\right)^{2}} \\
S D=\sqrt{\frac{502067}{38}-(80,55)^{2}} \\
S D=\sqrt{6520,35-6488,30} \\
S D=\sqrt{32,05} \\
S D=11,35
\end{gathered}
$$

Hasil tersebut menunjukkan bahwa standar deviasi variabel hasil belajar siswa sebesar 11,35. Nilai standar deviasi yang diperoleh menunjukkan keragaman data atau variasi data. Hasil dari analisis ratarata yakni 86,15>11,35 standar deviasi. Semakin tinggi standar deviasi yang diperoleh maka semakin banyak keragaman datanya yang berarti terdapat perbedaan nilai yang terlalu jauh.

Analisis persentase dilakukan setelah memperoleh analisis rata-rata dan diketahui jumlah skor yang diperoleh keseluruhan, $\mathrm{n}=\Sigma \mathrm{FX}$ yaitu 3274. Nilai yang diharapkan $(\mathrm{N})$ yaitu jumlah responden dikali skor maksimal yakni 38 × $100=3800$. Sehingga:

$$
\begin{aligned}
\mathrm{P} & =\frac{n}{N} \times 100 \% \\
& =\frac{3274}{3800} \times 100 \% \\
& =86,15 \%
\end{aligned}
$$

Hasil tersebut menunjukkan persentase skor variabel prestasi belajar siswa adalah 86,15\%. Maka diketahui bahwa hasil belajar siswa kelas V SD Gugus II Kecamatan Tanete Riattang yakni berada pada kategori kuat.

Berdasarkan data hasil belajar siswa yang diperoleh, agar lebih memudahkan dalam membaca data maka terlebih dahulu ditentukan kelas dari masing-masing kategori. Diketahui mean/nilai rata-rata 86,15 dan standar deviasi 11,35. Selanjutnya kelas dari masing-masing kategori dirincikan berikut:

1) Kelompok tinggi

$$
\begin{aligned}
& X \geq M+1 S D \\
& X \geq 86,15+1(11,35) \\
& X \geq 86,15
\end{aligned}
$$

2) Kelompok sedang

$$
\begin{aligned}
& (\mathrm{M}-1 \mathrm{SD}) \leq \mathrm{X}<(\mathrm{M}+\mathrm{SD}) \\
& 86,15-1(11,35) \leq \mathrm{X}<86,15+ \\
& 11,35 \\
& 74,8 \leq \mathrm{X}<97,5 \\
& \text { 3) } \text { Kelompok kurang } \\
& (\mathrm{X}<\mathrm{M}-1 \mathrm{SD}) \\
& \mathrm{X}<86,15-1(11,35) \\
& \mathrm{X}<74,8
\end{aligned}
$$


Sehingga diperoleh tabel dan diagram lingkaran sebagai berikut:

Tabel 3. Kategori Hasil Belajar IPA Siswa Kelas V SD Gugus II

\begin{tabular}{cccc}
\hline \multirow{2}{*}{ Nilai interval } & \multicolumn{2}{c}{ Frekuensi } & \multirow{2}{*}{ Kategori } \\
\cline { 2 - 3 } $\mathrm{X} \geq 97,5$ & Frekuensi & $\%$ & \\
$74,8 \leq \mathrm{X}<97,5$ & 0 & 0 & Tinggi \\
$\mathrm{X}<74,8$ & 38 & 100 & Sedang \\
\hline Total & 0 & 0 & Kurang \\
\hline
\end{tabular}

Sumber : Guru Kelas V Gugus II, 2021

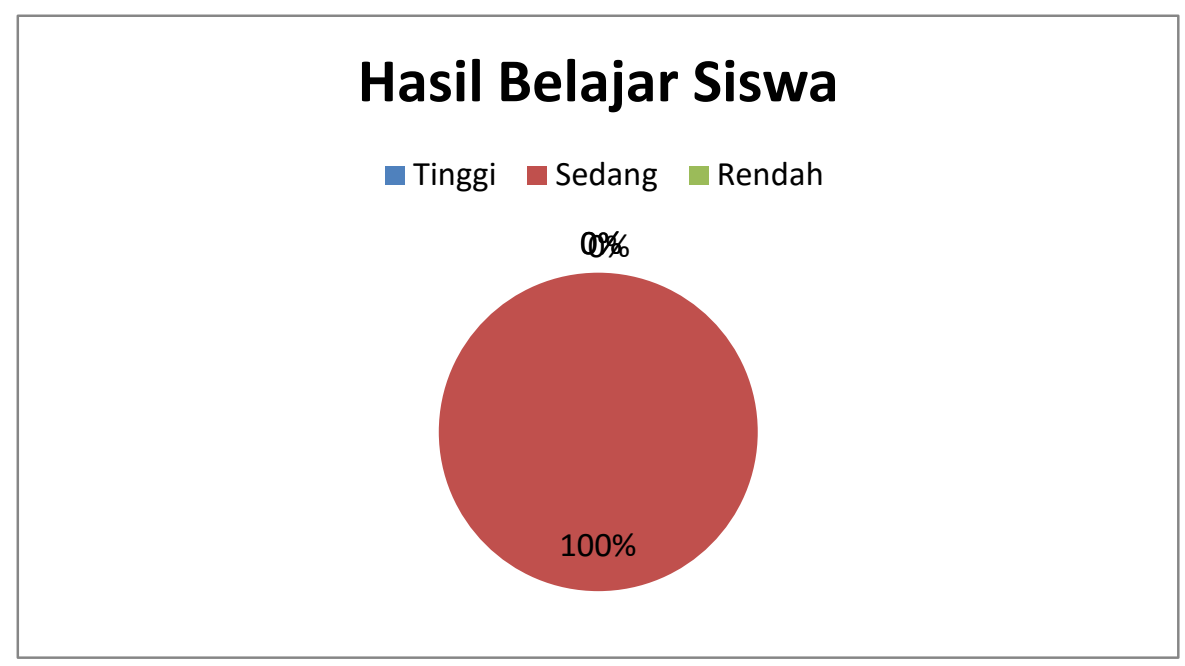

Gambar 3.Diagram Kategori Hasil Belajar IPA Siswa SD Gugus II

Pengkategorian nilai hasil persentase sebesar $0 \%$ jawaban belajar IPA digambarkan pada tabel tersebut berada pada kategori tinggi, dan gambar 3. Pada nilai terendah dan kategori dengan jumlah siswa terdapat 0 siswa dengan persentase terbanyak terdapat pada kategori sebesar $0 \%$, jawaban tersebut sedang dengan jumlah siswa 38 termasuk dalam kategori kurang, pada dengan persentase $100 \%$. nilai tertinggi terdapat 0 siswa dengan 
Tabel 4. Distribusi Frekuensi Hasil Belajar IPA Siswa Kelas V SD Gugus II

\begin{tabular}{lccc}
\hline Interval kelas & $\mathbf{f}$ & $\mathbf{x}$ & $\mathbf{f x}$ \\
\hline $76-78$ & 3 & 77 & 231 \\
\hline $79-81$ & 1 & 80 & 80 \\
\hline $82-84$ & 5 & 83 & 415 \\
\hline $85-87$ & 16 & 86 & 1376 \\
\hline $88-90$ & 8 & 89 & 712 \\
\hline $91-93$ & 5 & 92 & 460 \\
\hline$\Sigma$ & 38 & & 3274 \\
\hline
\end{tabular}

Sumber : Guru Kelas V SD Gugus II, 2021

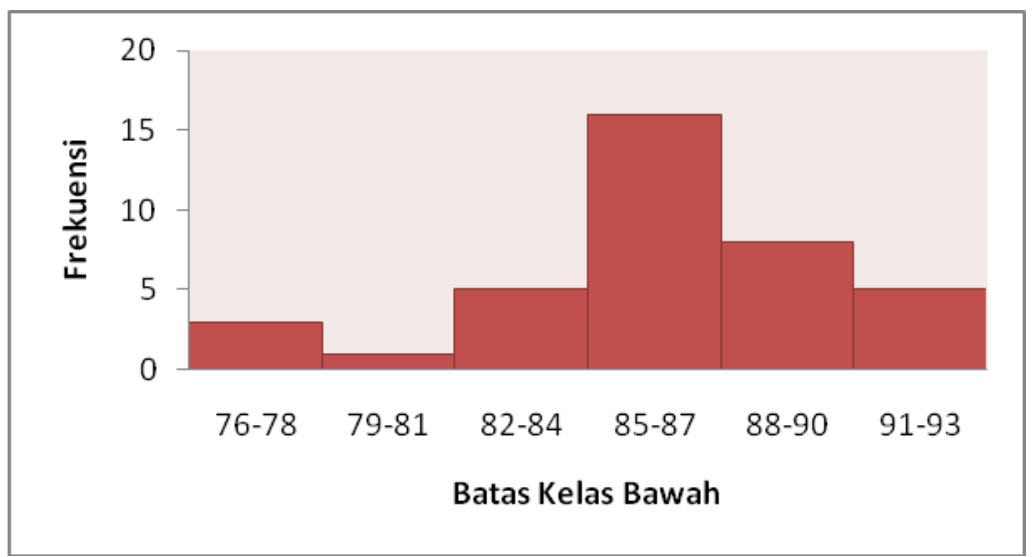

Gambar 4. Grafik Histogram Hasil Belajar IPA Siswa Kelas V SD Gugus II

Dengan demikian, dapat disimpulkan bahwa frekuensi paling tinggi terdapat pada kelas interval 85-

87 dengan jumlah siswa sebanyak 16.

Berdasarkan hasil perhitungan $r_{x y}=\frac{38(268590)-(3114) \cdot(3274)}{\sqrt{\left[38.256690-(3114)^{2}\left[\left[38.28483-(3274)^{2}\right]\right]\right.}}$

$r_{x y}=\frac{10206420-10185894}{\sqrt{[9754220-9696996][10722954-10699441]}}$ pada lampiran, maka diperoleh besaran-besaran statistik: $\mathrm{N}=38, \Sigma \mathrm{X}$ $r_{x y}=\frac{20526}{\sqrt{[57224][23513]}}$ $=3114, \Sigma Y=3274$, Untuk mengetahui nilai koefisien korelasi, maka digunakan rumus korelasi pearson product moment sebagai berikut:

$r_{s y}=\frac{N \sum X Y-\left(\sum X\right) \cdot\left(\sum Y\right)}{\sqrt{\left(N \cdot \sum X^{2}-\left(\sum X\right)^{2}\right) \cdot\left(N \sum Y^{2}-\left(\sum Y\right)^{2}\right)}}$

$r_{x y}=\frac{20526}{3668116563}$

$r_{x y}=0,5595$

Berdasarkan hasil perhitungan tersebut, diperoleh $r_{x y}$ sebesar 0,5595.maka diperoleh bahwa tingkat 
hubungan kedua variabel tergolong sedang karena berada pada rentang $0,40-0,599$.

Uji-t dengan rumus sebagai berikut:

$$
\begin{aligned}
& \text { thitung }=\frac{r \sqrt{n-2}}{\sqrt{1-r^{2}}} \\
& \text { thitung }==\frac{0,5595 \sqrt{38-2}}{\sqrt{1-0.5595^{2}}} \\
& \text { thitung }=\frac{0,5538 \times 6}{\sqrt{1-0,3130}} \\
& \text { thitung }=\frac{3,357}{\sqrt{0,687}} \\
& \text { thitung }=\frac{3,357}{0,8288} \\
& \text { thitung }=4,050
\end{aligned}
$$

Dengan demikian dapat dikatakan bahwa terdapat hubungan yang signifikan antara kompetensi profesional guru dengan hasil belajar IPA siswa Kelas V SD Gugus II Kecamatan Tanete Riattang Kabupaten Bone.

\section{PEMBAHASAN}

Hasil analisis yang telah diuraikan sebelumnya menunjukkan bahwa terdapat hubungan yang signifikan antara kompetensi profesional dengan hasil belajar siswa.

Berdasarkan hasil analisis
statistik deskriptif hubungan
kompetensi profesionaldenganhasil
belajar IPA siswa Kelas V SD Gugus II
Kecamatan Tanete Riattang
Kabupaten Bone, kompetensi profesional memiliki nilai rata-rata sebesar 81,76 dan nilai persentase sebesar $81,76 \%$ yang berada pada kategori baik karena terletak pada rentang 66\%-79\%. Hal ini mengindikasikan bahwa kompetensi profesional guru sudah baik terbukti dengan tingginya nilai rata rata dan juga persentase yang didapatkan peneliti setelah penelitian. Kondisi tersebut terjadi karena guru sudah mampu menguasai indikator esensial yang ada di dalam kompetensi profesional seperti menguasai materi secara luas dan mendalam,mengerti dan dapat menerapakan teori belajar sesuai dengan bidang studinya. Hal ini sejalan dengan pendapat yang dikemukakan oleh Buchari (2009) bahwa "Kompetensi profesional adalah kemampuan yang berhubungan dengan penyelesaian tugas-tugas keguruan" (Kurniati, 2014, h. 67).

Sementara pada hasil belajar IPA siswa Kelas V SD Gugus II Kecamatan Tanete Riattang Kabupaten Bone memperoleh nilai rata-rata sebesar 86,15 dan persentase $86,15 \%$ yang berada pada kategori baik karena terletak pada 
rentang 66\%-79\%. Dengan demikian, dapat diketahui bahwa siswa memiliki rata-rata nilai yang baik. Hal tersebut dapat dilihat dari nilai IPA siswa kelas V SD Gugus II Kecamatan Tanete Riattang Kabupaten Bone baik itu nilai pengetahuan maupun nilai keterampilan. Siswa dikatakan berhasil dalam belajar apabila siswa mencapai tujuan pembelajaran. Dalam dunia pendidikan hasil belajar berkaitan dengan perubahanperubahan pada diri siswa, baik yang menyangkut aspek kognitif, afektif dan psikomotorik. Hal ini sesuai dengan pendapat yang dikemukakan oleh Susanto (2015), "hasil belajar yaitu perubahan-perubahan yang terjadi pada diri siswa, baik yang menyangkut aspek kognitif, afektif, dan psikomotor sebagai hasil dari kegiatan belajar" (h.5).".

Analisis korelasi person product moment, digunakan untuk mengetahui keeratan hubungan antara kompetensi profesional dengan hasil belajar siswa Kelas V SD Gugus II Kecamatan Tanete Riattang Kabupaten Bone dengan diperoleh $r_{x y}$ sebesar 0,5595. Hasil perhitungan tersebut disesuaikan dengan tabel 4 tabel interpretasi koefisien korelasi, maka diperoleh bahwa tingkat hubungan kedua variabel tergolong sedang karena berada pada rentang $0,40-0$, 599. Hasil koefisien korelasi kedua variabel kemudian diuji menggunakan uji-t dan didapatkan thitung sebesar 4,050 dan tabel sebesar 1,66830. Ternyata harga thitung lebih besar dari tabel yang artinya koefisien korelasi bersifat signifikan, sehingga $\mathrm{H} 0$ ditolak dan Ha diterima. Maksudnya adalah terdapat hubungan kompetensi profesional gurudenganhasil belajar IPA siswa Kelas V SD Gugus II Kecamatan Tanete Riattang Kabupaten Bone.Dimana semakin baik kompetensi profesional guru maka semakin baik juga hasil belajar siswa.

\section{KESIMPULAN}

Berdasarkan rumusan masalah dan hasil penelitian, maka dapat dikemukakan kesimpulan bahwa Kompetensi Profesional Guru kelas V SD Gugus II Kecamatan Tanete Riattang Kabupaten Bone termasuk dalam kategoribaik, dibuktikan dengan meningkatnya hasil belajar siswa,hasil belajar siswa kelas V SD Gugus II Kecamatan Tanete Riattang Kabupaten Bone termasuk dalam 
kategori baik. Hal tersebut dipengaruhi oleh kompetensi profesional guruyang berada pada kategori baik, jadi dapat disimpulkan terdapat hubungan yang signifikan antara kompetensi profesional guru dengan hasil belajar IPA siswa Kelas V SD Gugus II Kecamatan Tanete Riattang Kabupaten Bone.

Berdasarkan hasil penelitian yang dilakukan, maka saran dari peneliti,guru hendaknya lebih memperhatikan kompetensi profesional mengingat betapa pentingnya untuk guru kuasai agar proses pembelajaran menjadi lebih efektif sehingga dapat meningkatkan hasil belajar siswa. Peneliti yang tertarik mengkaji masalah yang relevan dengan penelitian ini hendaknya melakukan penelitian yang lebih seksama dengan ruang lingkup yang lebih luas dan pembahasan yang lebih mendalam untuk mendapatkan informasi ilmiah mengenai pentingnya kompetensi profesional guru untuk meningkatkan hasil belajar siswa.

\section{DAFTAR PUSTAKA}

Agusta Kurniati. (2014). Hubungan Kompetensi Profesional Guru Terhadap Hasil Belajar Siswa. 5(2), 66-70. https://doi.org/10.31227/osf.io/tfnk4

Donni Juni Priansa. (2014). Kinerja Dan Professionalisme Guru (S. P. Ai Kasmanah (ed.)).

Dr. Jejen Musfah, M. . (2011). Peningkatan Kompetensi Guru Melalui Pelatihan dan Sumber Belajar Teori dan Praktik. Kencana.

Emzir. (2015). Metodologi Penelitian Pendidikan Kuantitatif dan Kualitatif. Rajawali pers.

Hakim, L. (2016). Pemerataan akses pendidikan bagi rakyat sesuai dengan amanat Undang-Undang Nomor 20 Tahun 2003 tentang Sistem Pendidikan Nasional. EduTech: Jurnal Ilmu Pendidikan Dan IImu Sosial, 2(1), 53-64.

Hariyanto, \& Suyono. (2011). Belajar dan Pembelajaran. PT Remaja Rosdakarya Offset.

Irjus Indrawan. (2020). BAB III Kompetensi Paedagogik. Guru Profesional, 23.

Mulyasa. (2013a). Standar Kompetensi dan Sertifikasi Guru. Remaja Rosdakarya. 
Mulyasa. (2013b). Uji Kompetensi dan Penilaian Guru.

Muslimin, M., \& Amran, M. (2020). Penerapan Pembelajaran Keterampilan Proses Untuk Meningkatkan Pemahaman Siswa SD Kelas IV Pada Materi Konsep Energi Bunyi. JIKAP PGSD: Jurnal IImiah IImu Kependidikan, 4(2), 130. https://doi.org/10.26858/jkp.v4i2.13744

Purwanto. (2016). Evaluasi Hasil Belajar.

Ricky Pratama, Bukhari, M. H. (2017). Kemampuan Mengidentifikasi Unsur Intrinsik Cerita Pendek Siswa Kelas V Sd Negeri 16 Banda Aceh. Journal of Chemical Information and Modeling, 53(9), 1689-1699.

Rusman. (2016). Pembelajaran Tematik Terpadu, Teori,Praktik,dan Penilaian.

Sidabutar, F. (2017). Kompetensi Dasar Tata Surya Pelajaran Ipa Menggunakan Model Contextual Teaching And Learning ( Ctl ) Di Kelas Iv Sd Negeri 067258 Medan. Journal Of Phsysics and Science Learning, 01, 59-76.

Suarya, D., Santiyadnya, \& Arsa, S. (2018). Studi Evaluasi Profesionalisme Guru Prakarya Dan.7(1), 20-30.

Sugiyono. (2017). Metode Penelitian Pendidikan. Alfabeta.

Sugiyono, P. D. (2018). Metode Penelitian Pendidikan Pendekatan Kuantitatif, Kualitatif, dan $R \& D$ (27th ed.). Alfabeta.

Susanto, A. (2015). Teori Belajar dan Pembelajaran di Sekolah Dasar.

Suyanto dan Jihad. (2013). Menjadi professional Guru. Erlangga group. 